Poster Section

\title{
Hypoglycemic effect of Alloxan and Thymulin both diluted in Wistar rats with degeneration of beta cells islets of Langerhans
}

\author{
Ruggero Zalla Neto스 ${ }^{1}$ Patricia Moriguchi², Aline Rodrigues Chaves ${ }^{2}$, \\ Ingrid Lauren Brites de Oliveira ${ }^{2}$
}

\author{
${ }^{1}$ Pitágoras Faculty, Brazil \\ 2Paulista University (UNIP), Brazil
}

\begin{abstract}
Diabetic animals induced by alloxan show severe hyperglycemia and intense catabolism characterized by the absence of insulin. Therefore, the objective of this study is to assess whether the alloxan $6 \mathrm{CH}$, is able to reverse or mitigate the changes promoted by diabetes mellitus, as well as assess the effects of thymulin. In biological tests male Wistar rats were used induced to experimental diabetes by the administration of alloxan (iv $42 \mathrm{mg} / \mathrm{kg}$ ). The sample comprised four groups ( $=4$ ): $\mathrm{G} 1$ - control without the induction of diabetes, G2 diabetic without treatment, G3 - diabetic treated with thymulin $12 \mathrm{CH}$ and $\mathrm{G} 4$ - treated with alloxan $6 \mathrm{CH}$. The data were statistically analyzed by ANOVA followed by Tukey-Kramer test $(p<0.05)$. After treatment for 40 days slight decrease of glucose in animals treated with alloxan $(502 \pm 28) \mathrm{mg} / \mathrm{dl}$ and thymulin $(500 \pm 10)$ $\mathrm{mg} / \mathrm{dl}$ was observed compared with untreated animals $(563 \pm 23) \mathrm{mg} / \mathrm{dl}$. Remained unchanged feed intake and water, however, significant decrease of body weight in diabetic group $(96 \pm 21) \mathrm{g}$ was observed compared to animals treated with alloxan $(27 \pm 23) \mathrm{g}$ and thymulin $(20 \pm 16) \mathrm{g}$, fact not observed when the last two groups are compared with the control $(5.1 \pm 3.9) \mathrm{g}$. Significant reduction in the percentage of lymphocytes in diabetic animals $(44.8 \pm 2.4) \%$ and increase in the group treated with thymulin $(12 \mathrm{CH})(83.3 \pm 4.5) \%$ was checked, when compared to the others. Animals treated with alloxan and thymulin showed clinical improvement. Based on these findings it is concluded that alloxan and thymulin improve the general state of the animal, and suggest inhibition of strong catabolism observed in diabetic animals without treatment.
\end{abstract}

Keywords: Alloxan, Thymulin, Diabetes.

\section{(c)) BY-Nc-ND Licensed to GIRI}

Support: authors declare that this study received no funding

Conflict of interest: authors declare there is no conflict of interest

Received: 01 June 2012; Revised: 10 August 2012; Published: 30 September 2012.

Correspondence author: Ruggero Zalla Neto, ruzaneto@gmail.com

How to cite this article: Zalla Neto R, Moriguchi P, Chaves AR, de Oliveira ILB. Hypoglycemic effect of Alloxan and Thymulin both diluted in Wistar rats with degeneration of beta cells islets of Langerhans. Int J High Dilution Res [online]. 2012 [cited YYYY Month dd]; 11(40):184-184. Proceedings of the XXVI GIRI Symposium; 2012 Sep 20-22; Florence (Italy). GIRI; 2012; Available from: http://www.feg.unesp.br/ ojs/index.php/ijhdr/article/view/579/598 